\title{
Extraction of Flavonoids from Corn Silk and Biological Activities In Vitro
}

\author{
Shuangqi Tian (D), Yue Sun, and Zhicheng Chen \\ College of Food Science and Engineering, Henan University of Technology, Zhengzhou 450001, China \\ Correspondence should be addressed to Zhicheng Chen; chen_1958@163.com
}

Received 12 January 2020; Revised 2 February 2021; Accepted 25 February 2021; Published 4 March 2021

Academic Editor: quancai sun

Copyright (c) 2021 Shuangqi Tian et al. This is an open access article distributed under the Creative Commons Attribution License, which permits unrestricted use, distribution, and reproduction in any medium, provided the original work is properly cited.

\begin{abstract}
When harvesting corn, corn silk was discarded as waste, including the compounds isolated and identified from corn silk such as flavonoids, sterols, alkaloids, polysaccharides, organic acids, volatile oils, trace elements, and multivitamins. It not only pollutes the environment but also wastes resources. In this paper, extraction methods commonly used for extracting flavonoids from corn silk were reviewed, such as reagent method, enzymatic method, microwave, supercritical $\mathrm{CO}_{2}$ extraction, ultrasonic, and microwave-assisted ultrasonic. Flavonoids are natural antioxidants and have application value in scavenging free radicals, inhibiting bacteria, and regulating blood lipids. The in vitro biological activities of flavonoids from corn silk extracted by different extraction methods were also compared.
\end{abstract}

\section{Introduction}

During the metabolism of the human body, substances such as reactive oxygen species and free radicals with strong oxidizing properties will be produced $[1,2]$. If these substances are not removed in time, they would cause damage to biological membranes and cell functions and then cause aging, cardiovascular disease, and cancer [3]. Antioxidants could scavenge free radicals, thereby reducing their harm to the human body [4]. However, due to the potential safety hazards of synthetic antioxidants, the development of low-toxic, safe, and efficient natural antioxidants has become a research hotspot [5]. In recent years, many researchers have found that flavonoids are important secondary metabolites that were widely present in plant tissues [6-8]. Biological activities in vitro aroused great interest of many researchers. At present, the main problems on the antioxidant activity of flavonoids are the low purity of the extracts and the low content of potent flavonoids [9-11].

Flavonoids commonly found in plants are an indispensable part of the human diet, especially for compounds found in corn silk, which have antioxidant properties and potential health benefits, and have attracted extensive attention [12]. Corn silk, also named as Maydis stigma (Zea mays hairs), which refers to the stigmas of the maize female flowers, is frequently used in traditional Chinese herbal medicines [13]. Corn silk is made from stigmas, the yellowish thread-like strands from the female flower of corn with various therapeutic values and no documented toxicity [14]. Corn silk contains abundant flavonoids. The total amount of flavonoids varies greatly with the variety, and the content is from less than $0.1 \%$ to $3 \%[15,16]$. Flavonoids show a variety of biological activities, such as antioxidant, antibacterial, antidiabetic, and antifatigue, and also have some clinical applications [16]. Microwave, ultrasonic, supercritical fluid extraction, and multiple extraction technologies were used to extract flavonoids effectively [16, 17]. As shown in Table 1, to date, several flavonoids such as maysin, apigmaysin, 3-methoxymaysine, ax-4-OHmaysin, and isoorientin-2" -O-a-L-rhamnoside have been isolated and identified from corn silk $[12,17,18]$. In order to clarify the extraction method and chemical composition of flavonoids in corn silk, this paper systematically studied the chemical components of corn silk and its biological activities in vitro.

\section{Extraction Methods of Flavonoids from Corn Silk}

About 29 flavonoids have been isolated from corn silk. Most of them are C-glycoside compounds and have the same 
TABLE 1: Structures and molecular weight of flavonoids or flavone glycosides from corn silk.

Structures of flavonoids or flavone glycosides

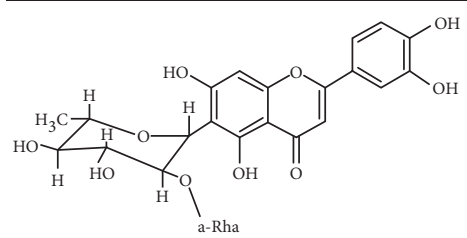

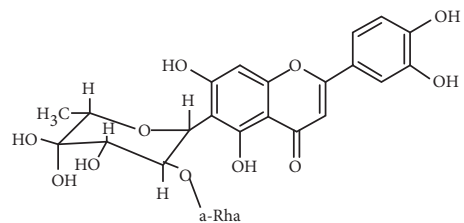

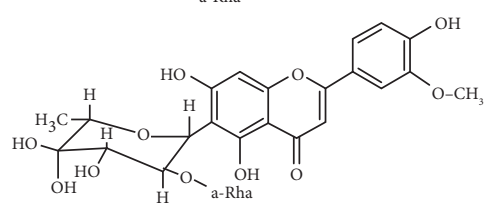

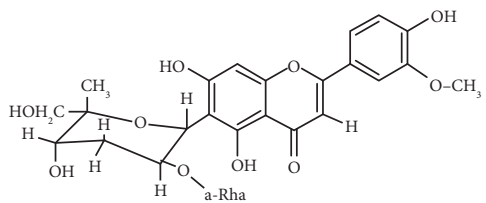

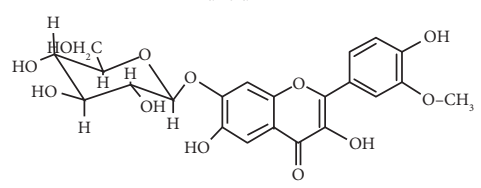

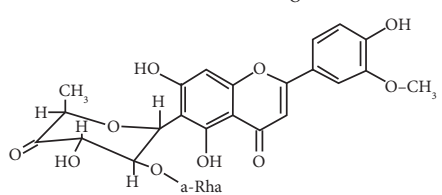

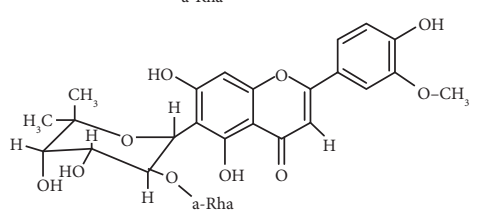

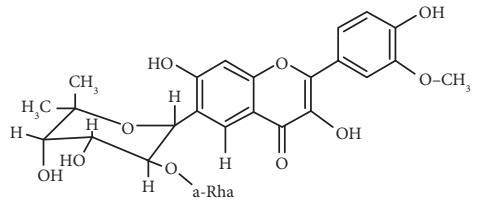

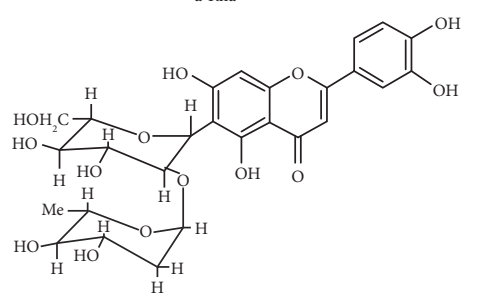
Chemical ingredients Molecular weight

7,4'-Dihydroxy-3' -methoxyflavone-2" -O- $\alpha$-L-rhamnosyl-6-Cfucoside 
TABLE 1: Continued.

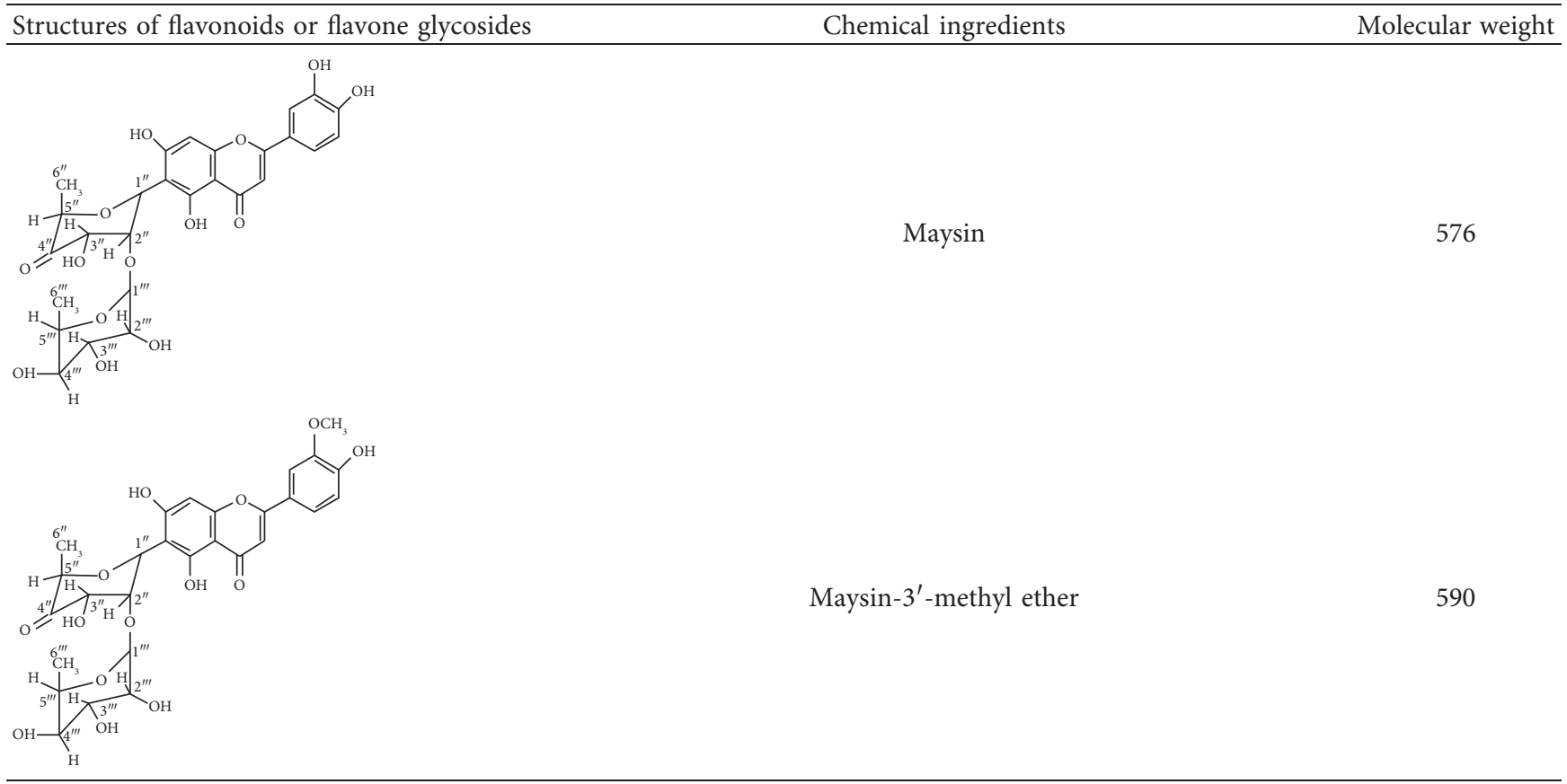

parent nucleus of luteolin. The flavonoids of corn silk show strong biological activities [19]. They are usually combined with sugars in corn silk to form C-glycosides, and a small part exists in a free form [20]. Flavonoids are easily soluble in organic solvents such as ethanol, methanol, ethyl acetate, and ether. Therefore, the extraction of flavonoids usually uses the ethanol reflux extraction method [21]. As shown in Figure 1, different steps may be involved in the preparation of flavonoids of corn silk. In recent years, with the rapid development of microwave, ultrasonic, supercritical fluid extraction, and multiple extraction technologies, many researchers have used them as an auxiliary technology for flavonoid extraction in order to save time and maximize the flavonoid extraction rate $[22,23]$. The advantages and disadvantages of various extraction methods are compared in Table 2.

2.1. Ethanol Reflux Extraction. Ethanol reflux extraction is a traditional method for flavonoid extraction, which is widely used in the extraction of flavonoids. Flavonoid aglycones are generally insoluble or insoluble in water and easily soluble in organic solvents such as methanol, ethanol, ethyl acetate, and ether. Therefore, taking advantage of the low price and nontoxicity of ethanol, the method of refluxing ethanol is used to remove flavonoids from corn silk [24]. The factors affecting the extraction of corn flavonoids mainly include extraction time, extraction temperature, extraction times, material-liquid ratio, and ethanol concentration. The optimized extraction process is relatively simple, and the extraction rate of corn flavonoids is relatively stable. Although the ethanol reflux extraction method has the advantages of simple operation and better extraction effect, it is associated with a large amount of extraction liquid and a long extraction time. It is not conducive to saving energy and cost and hence not suitable for large-scale production. High extraction yield $\left(5.32 \mathrm{mg} \cdot \mathrm{g}^{-1}\right)$ of total flavonoids was obtained under the optimal extraction conditions, which are $80^{\circ} \mathrm{C}$ for $3 \mathrm{~h}$ with corn silk over $60 \%$ ethanol ratio of $1: 30$ [25].

2.2. Aqueous Extraction. Aqueous extracts of corn silk showed a broad spectrum of antibacterial activity on the tested microorganisms. These derivatives could be potential alternatives to the traditional control of bacteria and fungi during food storage [26].

For aqueous extraction, $50 \mathrm{~g}$ of air-dried powder was placed in distilled water and boiled for $6 \mathrm{~h}$. At intervals of $3 \mathrm{~h}$, the solvent was removed in vacuum. The supernatant was collected. After $6 \mathrm{~h}$, the supernatant was concentrated to make the final volume to $100 \mathrm{ml}$. Finally, $50 \mathrm{~g}$ of material was extracted in $100 \mathrm{ml}$ of distilled water giving a concentration of $500 \mathrm{mg} / \mathrm{ml}$ [27].

2.3. Microwave-Assisted Extraction. Microwaves are electromagnetic waves with a frequency between $300 \mathrm{MHz}$ and $300 \mathrm{GHz}$ and a wavelength between $1 \mathrm{~mm}$ and $1 \mathrm{~m}$. During microwave extraction, polar substances in plant cells absorb microwave energy to generate a large amount of heat, which causes the intracellular temperature to rise rapidly and generate pressure [28]. The pressure breaks the cell membrane and cell wall, and the intracellular material is dissolved and released into the extract. Microwave-assisted extraction methods are either better or comparable with conventional solvent extraction methods [29, 30].

The process of microwave-assisted extraction (MAE) of total flavonoids from corn silk and the hypolipidemia in animal models were studied. The influence of solvent 


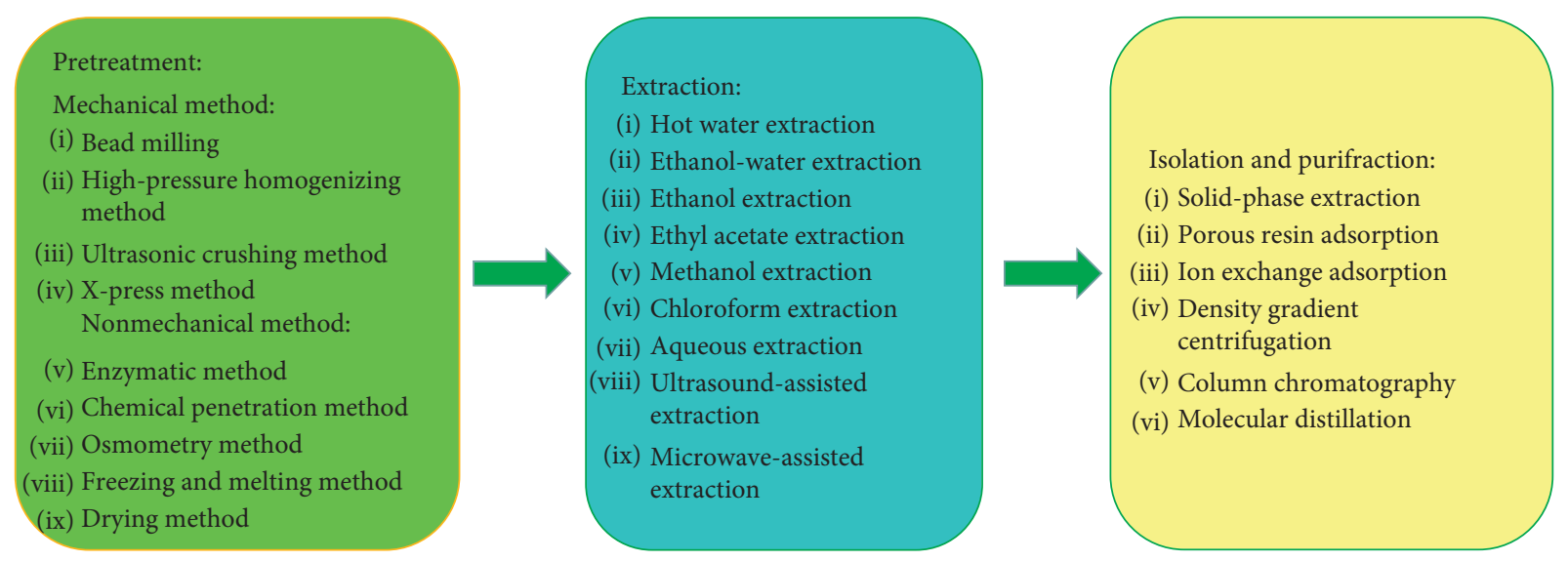

Figure 1: Different steps that may be involved in the preparation of flavonoids of corn silk.

TABLE 2: The advantages and disadvantages of various extraction methods.

\begin{tabular}{|c|c|c|}
\hline Extraction methods & Advantages & Disadvantages \\
\hline $\begin{array}{l}\text { Ethanol reflux } \\
\text { extraction }\end{array}$ & $\begin{array}{l}\text { Less dosage, short extraction time, less } \\
\text { impurities, complete extraction }\end{array}$ & Volatile and toxic \\
\hline Aqueous extraction & $\begin{array}{l}\text { Simple operation, low cost, suitable for large- } \\
\text { scale production }\end{array}$ & More impurities \\
\hline $\begin{array}{l}\text { Microwave-assisted } \\
\text { extraction }\end{array}$ & High selectivity, fast and efficient, stable quality & $\begin{array}{c}\text { The extraction time is too long and the temperature is too high, but } \\
\text { the extraction rate decreases }\end{array}$ \\
\hline $\begin{array}{l}\text { Ultrasonic-assisted } \\
\text { extraction }\end{array}$ & $\begin{array}{c}\text { Short extraction time and high yield without } \\
\text { heating }\end{array}$ & Small extraction scale, not suitable for large-scale production \\
\hline $\begin{array}{l}\text { Supercritical fluid } \\
\text { extraction }\end{array}$ & $\begin{array}{l}\text { Low extraction temperature, high extraction } \\
\text { rate, low solvent consumption, no pollution }\end{array}$ & $\begin{array}{l}\text { The separation selectivity is reduced, it is not easy to obtain a pure } \\
\text { substance, the investment is large, and the operating component is } \\
\text { high }\end{array}$ \\
\hline
\end{tabular}

concentration, microwave power, extraction time, and dose of solvent was investigated, and then, the orthogonal experiments were performed. Animal models of hyperlipidemia induced by a high-fat diet were established. The serum levels were, respectively, measured, including total cholesterol (TC), triglyceride (TG), low-density lipoprotein cholesterol (LDL-C), and high-density lipoprotein cholesterol (HDL-C). The optimum extraction parameters were determined as follows: ethanol concentration (60\%), power $(600 \mathrm{~W})$, extraction time $(16 \mathrm{~min})$, ratio of plant material to solvent (M/S) (1:20), and yield of extract (4.55\%). Corn silk total flavonoids (CSTFs) significantly lowered the serum TC, TG, and LDL-C levels. Furthermore, the serum lipid level was decreased by CSTF in hyperlipidemic animal models in a dose-dependent manner [31].

2.4. Ultrasonic-Assisted Extraction. Ultrasonic wave is a kind of sound wave with a frequency higher than $20000 \mathrm{~Hz}$. Ultrasonic waves form mechanical vibrations of medium particles in the material medium, which can cause the interaction of the medium [32]. Cavitation and thermal effects are the main effects of ultrasonic waves in the liquid. This is beneficial to increase the dissolution of flavonoids. The ultrasonic-assisted extraction method does not require any additional chemical reagents and does not destroy the flavonoid structure, so it is considered a good auxiliary extraction method [33]. Through a three-level, three-variable Box-Behnken design of response surface methodology (RSM) adopting yield as response, the optimal conditions were determined as follows: ultrasonic power of $500 \mathrm{~W}$, extraction time of $20 \mathrm{~min}$, material solvent ratio of $1: 20$, and ethanol concentration of $30 \%$. Under the optimum conditions, the extraction yield of total flavonoids was 1.13\% [34].

2.5. Supercritical Fluid Extraction. Supercritical fluid carbon dioxide $\left(\mathrm{SF}-\mathrm{CO}_{2}\right)$ extraction (SFE) of flavonoids from corn silk and its nitrite scavenging ability were investigated. The effects of extraction time, particle size, and cosolvent composition in terms of water content in ethanol were first optimized. Then, a Box-Behnken design combined with response surface methodology (RSM) was employed to study the effects of three independent variables (temperature, pressure, and cosolvent amount) on the extraction yield of flavonoids. A maximal extraction yield of flavonoids of approximately $4.24 \mathrm{mg} / \mathrm{g}$ of corn silk by SFE was obtained under optimal conditions (a temperature of $50.88^{\circ} \mathrm{C}$, a pressure of $41.80 \mathrm{MPa}$, a cosolvent amount of $2.488 \mathrm{~mL} / \mathrm{g}$, and an extraction time of $120 \mathrm{~min}$ with $0.4 \mathrm{~mm}$ particle sizes and $20 \%$ aqueous ethanol as the cosolvent). Furthermore, the nitrite scavenging ability of the flavonoid-enriched SFE extracts was assessed using the Griess reagent. The flavonoid-enriched SFE extracts exhibited the highest scavenging 
ability on nitrite $(88.1 \pm 3.04 \%)$ at the concentration of $500 \mathrm{~g} /$ $\mathrm{ml}$ and at $\mathrm{pH}$ 3.0. The nitrite scavenging ability of the extracts appeared to be concentration-dependent but negatively correlated with the $\mathrm{pH}$ [35].

\section{Biological Activities of Corn Silk}

As shown in Table 3, corn silk shows a variety of biological activities, such as antioxidant, antibacterial, antidiabetic, and antifatigue, and also has some clinical applications $[36,37]$.

3.1. Antioxidant Activity of Corn Silk. Radicals are molecules or fragments of molecules that possess an unpaired electron in their outer orbital. As a result of this molecular instability, radicals are highly reactive and can promote damaging oxidation reactions with cellular proteins, lipids, or DNA, leading to oxidative stress and impaired cellular function [38].

The flavonoids in corn silk have good antioxidant effects, which are mainly manifested in reducing free radical generation and scavenging free radicals [39]. Antioxidant activity of corn silk $70 \%$ acetone-water extract was determined by ferric reducing antioxidant power (FRAP) test. The results showed that the antioxidant activity of corn silk extract had a good correlation with total polyphenol content $\left(R^{2}=0.9306\right)$ [40]. The relationships between phytochemicals and antioxidant activity in corn silk were evaluated and it was found that antioxidant activity was correlated with total phenolics and total flavonoids [41]. The influence of variety and harvest maturity on phytochemical content and antioxidant activity in corn silk was studied. The results showed that different parts of corn silk also differ in antioxidant activity, and high pigmentation generally occurred at the early maturity phase, and it was related directly to high antioxidant activity [42]. The nutritional compositions and antioxidative capacity from the silk obtained by immature corn and mature corn were studied [16]. The result showed that both ethanol extracts of immature and mature silks possessed strong free radical scavenging capacity compared to the water and ethyl acetate extract. It was reported that the antioxidant and free radical scavenging activities of extract and fractions from corn silk were evaluated by using in vitro antioxidant models. The results showed that $N$-butanol fraction, which demonstrated the highest total phenolic and flavonoid contents, exhibited the highest antioxidant and free radical scavenging activities rather than petroleum ether fraction, ethyl acetate fraction, and water fraction [4]. Antioxidant activity of the flavonoid-rich extract from corn silk was studied in vitro and in vivo. The results showed that the IC50 values of the extract for the 1,1-diphenyl-2-picrylhydrazyl (DPPH) radical and 2,2'-azino-bis (3-ethylbenzothiazoline-6-sulfonic acid) (ABTS) radical scavenging activity were 50.73 and $0.23 \mathrm{mg} / \mathrm{mL}$, respectively. Furthermore, the extract could significantly enhance total superoxide dismutase (T-SOD) activity, reduce malondialdehyde (MDA) content in the serum, increase glutathione content, and decrease protein carbonyl content in the liver tissue [43]. Antioxidant activity of crude flavonoid extract using STZ- induced diabetic mice was studied. The results showed that the MDA values were significantly reduced [15].

3.2. Antibacterial Activity ofCorn Silk. Neucere reported that water extract from corn silk could inhibit the growth of Aspergillus. The active ingredients were showed to contain chitosan and dextran according to the analysis of electrophoresis, both of which had antibacterial activity [44]. The antibacterial activity of corn silk extracts against seven kinds of common pathogens and food spoilage bacteria was investigated. Various extracts were studied on the antibacterial properties, and the results showed that $90 \%$ ethanol extract had the best antibacterial effect. In addition, acidic and neutral environment could enhance the antibacterial effects of the extracts. The antibacterial activity of ethanol extracts from corn silk was also studied [45]. Two flavonoid glycosides (compounds I and II) were isolated from $n$-butanol fraction of methanol extract of corn silk. The chemical structures of the compounds were elucidated as maysin (I) and maysin- $3^{\prime}$-methyl ether (II) by means of different analytical methods such as UV, IR, NMR, and MS (ESI) analyses and by comparison with those reported in the literature for the compounds. The antimicrobial activities of maysin (I) and maysin-3'-methyl ether (II) were studied against twelve bacteria and one yeast. The sensitivity of the compounds $(2.0 \mathrm{mg} / \mathrm{mL})$ towards bacteria was compared with that of standard gentamycin $(50 \mu \mathrm{g} / \mathrm{mL})$. Flavonoid glycosides showed a wider range of activity towards Grampositive and Gram-negative bacteria. Comparatively, compound I exerted the highest antibacterial activity towards Gram-positive bacteria than compound II. In comparison with gentamycin, compound I showed significantly $(p<0.05)$ higher activity against the tested bacteria except Enterobacter aerogenes, Salmonella paratyphi, and Proteus mirabilis where it exerted statistically $(p<0.05)$ similar activity with gentamycin. But it showed lower activity towards Pseudomonas aeruginosa than gentamycin. Maysin$3^{\prime}$-methyl ether (II) showed comparatively lower activity than I; it seems that the presence of methoxyl substitution on the $\mathrm{C}-3^{\prime}$ position slightly decreases the sensitivity towards bacteria [46].

3.3. Antidiabetic Activity of Corn Silk. Antidiabetic activity of corn silk flavonoids (CSFs) was studied on STZ-induced diabetic mice. The results revealed that treatment with $300 \mathrm{mg} / \mathrm{kg}$ or $500 \mathrm{mg} / \mathrm{kg}$ of CSFs significantly increased the body weight, water consumption, and especially the blood glucose concentration of diabetic mice, which indicated their potential antidiabetic activities. Antidiabetic activity of corn silk crude polysaccharides on streptozotocin-induced hyperglycemic rats was studied, and its effects on hyperlipidemia, nerve excitability, and fatigue resistance were investigated. The results showed that the polysaccharides had a certain hypoglycemic effect on diabetic rats, and it also improved the symptoms of emaciation and polydipsia in diabetic rats, but the hypoglycemic effect was not as obvious as that of positive control metformin [47]. Antidiabetic activity of corn silk methanolic extract on glucose uptake by 
TABLE 3: Bioactivity and extraction method of flavonoids or flavone glycosides from corn silk.

\begin{tabular}{|c|c|c|c|c|}
\hline Bioactivity & Extraction method & Results & $\begin{array}{l}\text { Producing } \\
\text { area }\end{array}$ & References \\
\hline \multirow{3}{*}{$\begin{array}{l}\text { Antioxidant } \\
\text { activity }\end{array}$} & Ethanol-water extraction & $\begin{array}{l}\text { The percentage of DPPH radical scavenged by CS } \\
\text { extract was } 92.6 \text { at a concentration of } 1.6 \mathrm{mg} / \mathrm{ml}^{-1}\end{array}$ & Iran & {$[54]$} \\
\hline & $\begin{array}{l}\text { Three separate solvents (ethyl } \\
\text { acetate, ethanol, and water) }\end{array}$ & $\begin{array}{c}\text { The ABTS inhibition of immature and mature silks was } \\
\text { ranged from } 13.4 \% \text { to } 35 \% \text { and } 15.56 \% \text { to } 44.36 \% \text {, } \\
\text { respectively }\end{array}$ & Malaysia & {$[16]$} \\
\hline & Ultrasound-assisted extraction & $\begin{array}{l}\text { FRAP value of total flavonoids extracted from corn silk } \\
\text { was } 467.59 \mu \mathrm{mol} / \mathrm{L}\end{array}$ & China & {$[34]$} \\
\hline \multirow{3}{*}{$\begin{array}{l}\text { Antibacterial } \\
\text { activity }\end{array}$} & $\begin{array}{l}\text { The petroleum ether (PECS), } \\
\text { chloroform (CECS), and methanol } \\
\text { (MECS) extractions }\end{array}$ & $\begin{array}{c}\text { PECS, MECS, and flavonoids were active against eleven } \\
\text { bacteria out of twelve bacteria. CECS was active only } \\
\text { against five bacteria }\end{array}$ & Malaysia & {$[46]$} \\
\hline & $\begin{array}{c}\text { Ethanol, chloroform, and methanol } \\
\text { extractions }\end{array}$ & $\begin{array}{l}\text { Ethanol extract showed significant antimicrobial } \\
\text { activity against both Gram-positive bacteria (13.17 to } \\
9.45 \mathrm{mg} / \mathrm{ml}) \text { and Gram-negative bacteria (12.36 to } \\
8.15 \mathrm{mg} / \mathrm{ml}) \text { bacteria }\end{array}$ & Bangladesh & {$[55]$} \\
\hline & Aqueous extraction & $\begin{array}{l}\text { The antimicrobial activity against Staphylococcus } \\
\text { aureus and Bacillus subtilis is } 500 \mathrm{mg} / \mathrm{ml} \text { and } 62.5 \mathrm{mg} / \\
\mathrm{ml} \text {. The minimum inhibitory concentration to Candida } \\
\text { albicans is } 125 \mathrm{mg} / \mathrm{ml}\end{array}$ & China & {$[27]$} \\
\hline $\begin{array}{l}\text { Antidiabetic } \\
\text { activity }\end{array}$ & Ethanol extraction & $\begin{array}{l}\text { Treatment with } 300 \mathrm{mg} / \mathrm{kg} \text { or } 500 \mathrm{mg} / \mathrm{kg} \text { of corn silk } \\
\text { flavonoids significantly reduced the body weight loss, } \\
\text { water consumption, and especially the blood glucose } \\
\text { (BG) concentration of diabetic mice }\end{array}$ & China & {$[15]$} \\
\hline \multirow{2}{*}{$\begin{array}{l}\text { Antifatigue } \\
\text { activity }\end{array}$} & Hot ethanol continuous extraction & $\begin{array}{l}\text { Swimming exercise results indicated that corn silk } \\
\text { flavonoids had antifatigue activity of mice by inhibiting } \\
\text { the production of blood lactic acid }\end{array}$ & China & {$[17]$} \\
\hline & Hot ethanol continuous extraction & $\begin{array}{l}\text { Corn silk flavonoids could elevate the exercise } \\
\text { tolerance of mice and provide protection against } \\
\text { oxidative stress induced by exhaustive exercise in mice }\end{array}$ & China & {$[14]$} \\
\hline
\end{tabular}

isolated rat hemidiaphragm was studied. The results showed that the treatment of corn silk increased the uptake of glucose by isolated rat hemidiaphragm significantly and was found to be more effective than insulin [48]. Corn silk aqueous extract was also shown to exhibit potent and moderate inhibitory potential against $\alpha$-amylase and $\alpha$-glucosidase in vitro, respectively [49]. Corn silk aqueous extract treatment markedly reduced hyperglycemia in alloxan-induced diabetic mice. According to the study, the mechanism of the hypoglycemic effect was through increasing insulin level and repairing the injured $\beta$-cells instead of increasing glycogen and inhibiting gluconeogenesis [50]. The hypoglycemic effect of corn silk flavonoids was studied on alloxan-induced diabetic mice, and the results showed that corn silk flavonoids could significantly reduce the level of blood glucose of diabetic mice and significantly slowed down the weight loss of diabetic mice. In addition, corn silk flavonoids had an obvious improving effect on the activity of superoxide dismutases in the diabetic mice and had a certain inhibitory effect on the production of lipid peroxide (MDA), which indicated that the hypoglycemic effect might be associated with antioxidant activity by improving the function of islet cells, especially $\beta$-cells. It was found that the combination of corn silk and binahong leaves could be more effective in repairing renal damage caused by oxidative stress [51].
3.4. Antifatigue Activity of Corn Silk. In order to clarify the mechanism of antifatigue activity of corn silk flavonoids, blood biochemical parameters were measured in the swimmingtreated mice. The swimming exercise was known to induce blood biochemical changes [52]. Blood biochemical parameters are shown in Table 3. It was found that the blood lactate and blood urea nitrogen concentrations of treatment groups were significantly lower than those of the control group $(p<0.05)$. The results suggest that corn silk flavonoids can inhibit the production of blood lactic acid during exercise and retard the formation of blood urea nitrogen (BUN) after exercise. It was known that the endurance capacity of the body markedly decreased if energy was exhausted. As glycogen was the important resource of energy during exercise, the increase of glycogen stored in the liver is advantageous to enhance the endurance of the exercise [53]. It was found that the hepatic glycogen concentration of treatment groups was higher than that of the control group $(p<0.05)$, and the increasing rates were 260.71 and $281.25 \%$, respectively. The results suggested that corn silk flavonoids could elevate hepatic glycogen concentration during exercise. However, the detailed mechanism was not clear. The possible reason is that corn silk flavonoids may increase the content of postexercise hepatic glycogen of mice by improving glycogen reserve, or by reducing the consumption of glycogen during exercise, or both. It still needs further study [17]. 


\section{Conclusions}

The biological activity process involves many physiological challenges, which are significantly affected by biologically active substances. In this paper, ethanol, microwave, ultrasonic, supercritical fluid extraction, and multiple extraction technologies were reviewed as impactful technologies for flavonoid extraction of corn silk. Lots of studies have shown the potential benefits of ingested flavonoids against some major selected risk factors. The antioxidant, antibacterial, antidiabetic, and antifatigue activities are also described, while in vitro and in vivo studies are mainly related to the possible mechanisms of action of flavonoids, which represent a closer approach for the substantiation of the effects of these molecules in humans and allow health benefits to be claimed for foods containing them. Corn silk shows a variety of biological activities, such as antioxidant, antibacterial, antidiabetic, and antifatigue and has some clinical applications. In the future, the structure-activity relationship of corn flavonoids should be explored in depth, and the advantages of multiple sciences should be used to provide a strong scientific basis for the further development of natural and effective new drugs, as well as a basis for the full development and utilization of corn flavonoid resources.

\section{Data Availability}

The data used to support the results of this study are included within the article.

\section{Conflicts of Interest}

The authors declare no conflicts of interest.

\section{Acknowledgments}

This research was funded by the specially funded project for the Construction of Modern Agricultural Industrial Technology System in Henan Province (S2015-02-G06) and Cultivation Programme for Young Backbone Teachers in Henan University of Technology.

\section{References}

[1] A. Shirkavand and H. R. Nazif, "Numerical study on the effects of blood perfusion and body metabolism on the temperature profile of human forearm in hyperthermia conditions," Journal of Thermal Biology, vol. 84, pp. 339-350, 2019.

[2] L. Wu, Z. Sun, A. Chen, X. Guo, and J. Wang, "Effect of astaxanthin and exercise on antioxidant capacity of human body, blood lactic acid and blood uric acid metabolism," Science \& Sports, vol. 34, no. 5, pp. 348-352, 2019.

[3] J. R. Ruiz, B. Martinez-Tellez, G. Sanchez-Delgado, F. J. Osuna-Prieto, P. C. N. Rensen, and M. R. Boon, "Role of human Brown fat in obesity, metabolism and cardiovascular disease: strategies to turn up the heat," Progress in Cardiovascular Diseases, vol. 61, no. 2, pp. 232-245, 2018.

[4] J. Liu, C. Wang, Z. Wang, C. Zhang, S. Lu, and J. Liu, "The antioxidant and free-radical scavenging activities of extract and fractions from corn silk (Zea mays L.) and related flavone glycosides," Food Chemistry, vol. 126, no. 1, pp. 261-269, 2011.

[5] M. V. Eberhardt, C. Y. Lee, and R. H. Liu, "Antioxidant activity of fresh apples,” Nature, vol. 405, no. 6789, pp. 903-904, 2000.

[6] A. Gurib-Fakim, "Medicinal plants: traditions of yesterday and drugs of tomorrow," Molecular Aspects of Medicine, vol. 27, no. 1, pp. 1-93, 2006.

[7] K. Higashi-Okai, M. Yamazaki, H. Nagamori, and Y. Okai, "Identification and antioxidant activity of several pigments from the residual green tea (Camellia sinensis) after hot water extraction," Journal of UOEH, vol. 23, no. 4, pp. 335-344, 2001.

[8] J. Yang, W. Shi, B. Li, Y. Bai, and Z. Hou, "Preharvest and postharvest UV radiation affected flavonoid metabolism and antioxidant capacity differently in developing blueberries (Vaccinium corymbosum L.)," Food Chemistry, vol. 301, Article ID 125248, 2019.

[9] J.-G. Xu, Q.-P. Hu, and Y. Liu, "Antioxidant and DNAprotective activities of chlorogenic acid isomers," Journal of Agricultural and Food Chemistry, vol. 60, no. 46, pp. 1162511630, 2012.

[10] K.-X. Zhu, C.-X. Lian, X.-N. Guo, W. Peng, and H.-M. Zhou, "Antioxidant activities and total phenolic contents of various extracts from defatted wheat germ," Food Chemistry, vol. 126, no. 3, pp. 1122-1126, 2011.

[11] M. Arivalagan, T. K. Roy, A. M. Yasmeen et al., "Extraction of phenolic compounds with antioxidant potential from coconut (Cocos nucifera L.) testa and identification of phenolic acids and flavonoids using UPLC coupled with TQD-MS/MS," LWT, vol. 92, pp. 116-126, 2018.

[12] S.-C. Ren, Z. Liu, and X.-L. Ding, "Isolation and identification of two novel flavone glycosides from corn silk (Stigma maydis)," Journal of Medical Plants Research, vol. 3, pp. 1009-1015, 2009.

[13] A. Kan, I. Orhan, G. Coksari, and B. Sener, "In-vitro neuroprotective properties of the Maydis stigma extracts from four corn varieties," International Journal of Food Sciences and Nutrition, vol. 63, no. 1, pp. 1-4, 2011.

[14] Q. I. Hu and Z. I. Deng, "Protective effects of flavonoids from corn silk on oxidative stress induced by exhaustive exercise in mice," African Journal of Biotechnology, vol. 10, pp. 31633167, 2011.

[15] Y. Zhang, L. Wu, Z. Ma, J. Cheng, and J. Liu, "Anti-diabetic, anti-oxidant and anti-hyperlipidemic activities of flavonoids from corn silk on STZ-induced diabetic mice," Molecules, vol. 21, p. 7, 2016.

[16] N. A. Rahman and W. I. Wan Rosli, "Nutritional compositions and antioxidative capacity of the silk obtained from immature and mature corn," Journal of King Saud University-Science, vol. 26, no. 2, pp. 119-127, 2014.

[17] Q.-L. Hu, L.-J. Zhang, Y.-N. Li, Y.-J. Ding, and F.-L. Li, "Purification and anti-fatigue activity of flavonoids from corn silk," International Journal of Physical Sciences, vol. 5, pp. 321-326, 2010.

[18] M. E. Snook, N. W. Widstrom, B. R. Wiseman, P. F. Byrne, J. S. Harwood, and C. E. Costello, "New C-4"-Hydroxy derivatives of maysin and $3^{\prime}$-methoxymaysin isolated from corn silks (Zea mays)," Journal of Agricultural and Food Chemistry, vol. 43, no. 10, pp. 2740-2745, 1995.

[19] T.-T. Yu, X.-X. Lu, X.-J. Lian, and Y.-Q. Zhang, "Composition analysis of flavonoids from corn silk with thin-layer chromatography and ultraviolet spectrophotometry," Food Science, vol. 29, pp. 477-481, 2008. 
[20] S. Ren, Q. Qiao, and X. L. Ding, "Antioxidative activity of five flavones glycosides from corn silk (Stigma maydis)," Czech Journal of Food Sciences, vol. 31, no. 2, pp. 148-155, 2013.

[21] E. M. Garcia-Castello, A. D. Rodriguez-Lopez, L. Mayor, R. Ballesteros, C. Conidi, and A. Cassano, "Optimization of conventional and ultrasound assisted extraction of flavonoids from grapefruit (Citrus paradisi L.) solid wastes," LWT-Food Science and Technology, vol. 64, no. 2, pp. 1114-1122, 2015.

[22] Y. Zhang, C. Liu, J. Li, Y. Qi, Y. Li, and S. Li, "Development of "ultrasound-assisted dynamic extraction" and its combination with CCC and CPC for simultaneous extraction and isolation of phytochemicals," Ultrasonics Sonochemistry, vol. 26, pp. 111-118, 2015.

[23] A. C. Waiss, B. G. Chan, C. A. Elliger et al., "Maysin, a flavone glycoside from corn silks with antibiotic activity toward corn Earworm," Journal of Economic Entomology, vol. 72, no. 2, pp. 256-258, 1979.

[24] H. Bai, C. Hai, M. Xi, X. Liang, and R. Liu, "Protective effect of maize silks (Maydis stigma) ethanol extract on radiationinduced oxidative stress in mice," Plant Foods for Human Nutrition, vol. 65, no. 3, pp. 271-276, 2010.

[25] J. Wu, M. Ye, and Z. Wang, "Extraction, purification and antihyperlipidemic activities of total flavonoids from corn silk," Pakistan Journal of Zoology, vol. 49, no. 6, pp. 2173-2179, 2017.

[26] A. S. Sahib, I. H. Mohammed, and S. J. Hamdan, "Use of aqueous extract of corn silk in the treatment of urinary tract infection," Journal of Complementary Medicine Research, vol. 1, no. 2, pp. 93-96, 2012.

[27] F. Xing, W. Lei, M. Tao, and Z. Qing, "Studies on antimicrobial activity of aqueous extract of maize silk," Applied Mechanics and Materials, vol. 140, pp. 426-430, 2011.

[28] V. Mandal, Y. Mohan, and S. Hemalatha, "Microwave assisted extraction an innovative and promising extraction tool for medicinal plant research," Pharmacognosy Reviews, vol. 1, no. 1, pp. 7-18, 2007.

[29] J. S. Roberts and K. A. Gerard, "Development and evaluation of microwave heating of apple mash as a pretreatment to pressing," Journal of Food Process Engineering, vol. 27, no. 1, pp. 29-46, 2004.

[30] I. V. Kubrakova and E. S. Toropchenova, "Microwave heating for enhancing efficiency of analytical operations (review)," Inorganic Materials, vol. 44, no. 14, pp. 1509-1519, 2008.

[31] Y. Zhang, D. Y. Sui, J. S. Zhou, and H. L. Zhou, "Microwaveassisted extraction and antihyperlipidemic effect of total flavonoids from corn silk," African Journal of Biotechnology, vol. 10, no. 65, pp. 14583-14586, 2011.

[32] K. N. Prasad, B. Yang, M. Zhao, J. Sun, X. Wei, and Y. Jiang, "Effects of high pressure or ultrasonic treatment on extraction yield and antioxidant activity of pericarp tissues of longan fruit," Journal of Food Biochemistry, vol. 34, no. 4, pp. 838-855, 2010.

[33] G. H. Rao, "Optimization of ultrasound-assisted extraction of cyanidin 3-rutinoside from litchi (Lichi chinensis Sonn.) fruit pericarp," Analytical Methods, vol. 2, no. 8, pp. 1166-1170, 2010.

[34] L.-L. Zheng, G. Wen, M.-Y. Yuan, and F. Gao, "Ultrasoundassisted extraction of total flavonoids from corn silk and their antioxidant activity," Journal of Chemistry, vol. 2016, Article ID 8768130, 5 pages, 2016.

[35] J. Liu, S. Lin, Z. Wang et al., "Supercritical fluid extraction of flavonoids from Maydis stigma and its nitrite-scavenging ability," Food and Bioproducts Processing, vol. 89, no. 4, pp. 333-339, 2011.
[36] P.-G. Pietta, "Flavonoids as antioxidants," Journal of Natural Products, vol. 63, no. 7, pp. 1035-1042, 2000.

[37] E. A. Alam, "Evaluation of antioxidant and antibacterial activities of Egyptian Maydis stigma (Zea mays hairs) rich in some bioactive constituents," Journal of American Science, vol. 7, pp. 726-729, 2011.

[38] N. Masuoka, M. Matsuda, and I. Kubo, "Characterisation of the antioxidant activity of flavonoids," Food Chemistry, vol. 131, no. 2, pp. 541-545, 2012.

[39] Z. A. Maksimović and N. Kovacević, "Preliminary assay on the antioxidative activity of Maydis stigma extracts," Fitoterapia, vol. 74, no. 1-2, pp. 144-147, 2003.

[40] Z. Maksimović, D. Malencić, and N. Kovacević, "Polyphenol contents and antioxidant activity of Maydis stigma extracts," Bioresource Technology, vol. 96, no. 8, pp. 873-877, 2005.

[41] E. Sarepoua, R. Tangwongchai, B. Suriharn, and K. Lertrat, "Relationships between phytochemicals and antioxidant activity in corn silk," International Food Research Journal, vol. 20, pp. 2073-2079, 2013.

[42] E. Sarepoua, R. Tangwongchai, B. Suriharn, and K. Lertrat, "Influence of variety and harvest maturity on phytochemical content in corn silk," Food Chemistry, vol. 169, pp. 424-429, 2015.

[43] K.-Z. Peng, X. Yang, H.-L. Zhou, and S.-X. Pan, "Safety evaluation, in vitro and in vivo antioxidant activity of the flavonoid-rich extract from Maydis stigma," Molecules, vol. 20, no. 12, Article ID 22102, 2015.

[44] S. Habtemariam, "Extract of corn silk (stigma of Zea mays) inhibits tumour necrosis factor- $\alpha$ - and bacterial lipopolysaccharide-induced cell adhesion and ICAM-1 expression," Planta Medica, vol. 64, no. 4, pp. 314-318, 1998.

[45] M. N. Khan, O. Ngassapa, and M. I. N. Matee, "Antimicrobial activity of Tanzanian chewing sticks against oral pathogenic microbes," Pharmaceutical Biology, vol. 38, no. 3, pp. 235-240, 2000.

[46] F. Nessa, Z. Ismail, and N. Mohamed, "Antimicrobial activities of extracts and flavonoid glycosides of corn silk (Zea mays L)," International Journal of Biotechnology for Wellness Industries, vol. 1, pp. 115-121, 2012.

[47] W. Zhao, Y. Yin, Z. Yu, J. Liu, and F. Chen, "Comparison of anti-diabetic effects of polysaccharides from corn silk on normal and hyperglycemia rats," International Journal of Biological Macromolecules, vol. 50, no. 4, pp. 1133-1137, 2012.

[48] M. Ghada, M. S. Eltohami, H. N. Adurahman, and M. M. E. Mudawi, "In vitro study of the effect of corn silk on glucose uptake by isolated rat HEMI-DIAPHRAGM," World Journal of Pharmaceutical Research, vol. 3, no. 4, pp. 21902195, 2014.

[49] S. Sabiu, F. H. O’Neill, and A. O. T. Ashafa, "Kinetics of $\alpha$-amylase and $\alpha$-glucosidase inhibitory potential of Zea mays Linnaeus (Poaceae), Stigma maydis aqueous extract: an in vitro assessment," Journal of Ethnopharmacology, vol. 183, pp. 1-8, 2016.

[50] J. Guo, T. Liu, L. Han, and Y. Liu, "The effects of corn silk on glycaemic metabolism," Nutrition \& Metabolism, vol. 6, no. 1, p. 47, 2009.

[51] E. Y. Sukandar, J. I. Sigit, and L. F. Adiwibowo, "Study of kidney repair mechanisms of corn silk (Zea mays L. Hair)Binahong (Anredera cordifolia (ten.) steenis) leaves combination in rat model of kidney failure," International Journal of Pharmacology, vol. 9, no. 1, pp. 12-23, 2013.

[52] T. Moriura, H. Matsuda, and M. Kubo, "Pharmacological study on Agkistrodon blomhoffii blomhoffii Boie. V. Antifatigue effect of the $50 \%$ ethanol extract in acute weight- 
loaded forced swimming-treated rats," Biological and Pharmaceutical Bulletin, vol. 19, pp. 62-66, 1996.

[53] B. Yu, Z.-X. Lu, X.-M. Bie, F.-X. Lu, and X.-Q. Huang, "Scavenging and anti-fatigue activity of fermented defatted soybean peptides," European Food Research and Technology, vol. 226, no. 3, pp. 415-421, 2008.

[54] M. A. Ebrahimzadeh, F. Pourmorad, and S. Hafezi, "Antioxidant activities of Iranian corn silk," Turkish Journal of Biology, vol. 32, pp. 43-49, 2008.

[55] S. Morshed and S. M. S. Islam, "Antimicrobial activity and phytochemical properties of corn (Zea mays L.) silk," SKUAST Journal of Research, vol. 17, no. 1, pp. 8-14, 2015. 